\title{
Buccinator Myomucosal Flap and Levator Muscle Repositioning in Management of Velopharyngeal Insufficiency Secondary to Cleft Palate Repair
}

\author{
AHMED SAMRA, M.Sc.*; AYMAN AMER, M.D.**; MOHAMED ELSHERBINEY, M.D.*; \\ ADHAM EL-SAIED, M.D.*; MAMDOUH ABOULHASSAN, M.D.*** and KAMAL ABDEL ELAH ALI, M.D.*
}

The Department of Pediatric Surgery*, Phoniatric Unit, Department of ENT**, Faculty of Medicine, Mansoura University and Department of Plastic Surgery***, Kasr Al-Ainy, Faculty of Medicine, Cairo University

\begin{abstract}
Background: Buccinator myomucosal flap and levator muscle repositioning is an alternative technique in the management of velopharyngeal insufficiency secondary to cleft palate repair.

Aim of Study: The goal of this study is to assess the effectiveness of the buccinators myomucosal flap and levator muscle repositioning in the management of velopharyngeal insufficiency secondary to cleft palate.

Patients and Methods: A prospective study was done on thirty patients who have velopharyngeal insufficiency after cleft palate repair and recommended for surgery by the phoniatrician. The period of the study was between August 2017 and August 2019. All cases were evaluated for speech assessment and videofluroscopy before the operation and 3 months after the operation. Successful speech outcome was defined as completely improved, improved, and not improved.

Results: Overall improvement of the speech was obtained in 25 cases $(83 \%)$ Nine of them $(30 \%)$ were completely improved, 16 of them (53\%) were improved by at least one grade, 5 cases $(17 \%)$ showed no improvement.

Conclusion: Buccinator myomucosal flap and levator muscle repositioning is a reliable efficient procedure for the management of VPI secondary to the cleft palate with minimal complications.
\end{abstract}

Key Words: Buccinator myomucosal flap - Levator muscle repositioning - Velopharyngeal insufficiency Cleft palate repair.

\section{Introduction}

VELOPHARYNGEAL insufficiency (VPI) occurs in about $20-30 \%$ of cases after primary cleft palate repair [1]. Velopharyngeal insufficiency results in hypernasality, nasal air emission, and poor quality of speech. The main causes of the VPI after palat-

Correspondence to: Dr. Ahmed Samra, The Department of Pediatric Surgery, Faculty of Medicine, Mansoura University oplasty are short palate and limited velar mobility. The most common VPI surgeries are pharyngeal flaps, sphincter pharyngoplasty, palatal muscle retro positioning, double opposing Z-plasty, and posterior pharyngeal wall augmentation [2]. This variety reflects the fact that there is no ideal technique. Moreover, each case needs a customized plan for management and a precise selection of the procedure. Obstructive sleep apnea, mouth breathing, hyponasality, nasal mucous flow, and/or disrupted facial growth are reported complications with those procedures [3].

Levator veli muscle repositioning and buccinator myomucosal flaps procedure goal is to restore the normal anatomy as far as we can, thus, improving the function. It also deals directly with the main causes of the VPI, it improves the movement of the velum and lengthens the short palate $[\mathbf{4 , 5}$.

The aim of this study is to assess the speech outcome and rate of complications in the patients undergoing levator muscle repositioning and buccinator myomucosal flaps for management of velopharyngeal insufficiency and whom had a history of cleft palate repair.

\section{Patients and Methods}

A prospective study was performed on 30 patients with a history of repaired cleft palate \pm -cleft lip who were operated upon by buccinator myomucosal flap and levator muscle repositioning for management of velopharyngeal insufficiency between August 2017 and August 2019. All cases were above 3 years with a short scared palate with manifesting VPI proved by APA and videofluroscopy. We included the cases who had previous velopharyngeal insufficiency surgeries. 
We excluded syndromic cases, delayed language development cases, neurologically impaired cases, and cases with incomplete medical records.

Preoperative assessment by experienced phoniatricis team included screening with the auditory perceptual assessment of all repaired cleft palate cases using standardized perceptual speech protocol. Patients determined to have VPI is then evaluated using videofluroscopy.

The operative technique included levator muscle repositioning using intravelar veloplasty or double opposing Z-plasty (Furlow) and posteriorly based buccinator myomucosal flaps for palatal lengthening (unilateral or bilateral) [6,7]. Briefly, one of two techniques were done for Levator muscle repositioning. The first one included transverse incision just posterior to the junction between hard

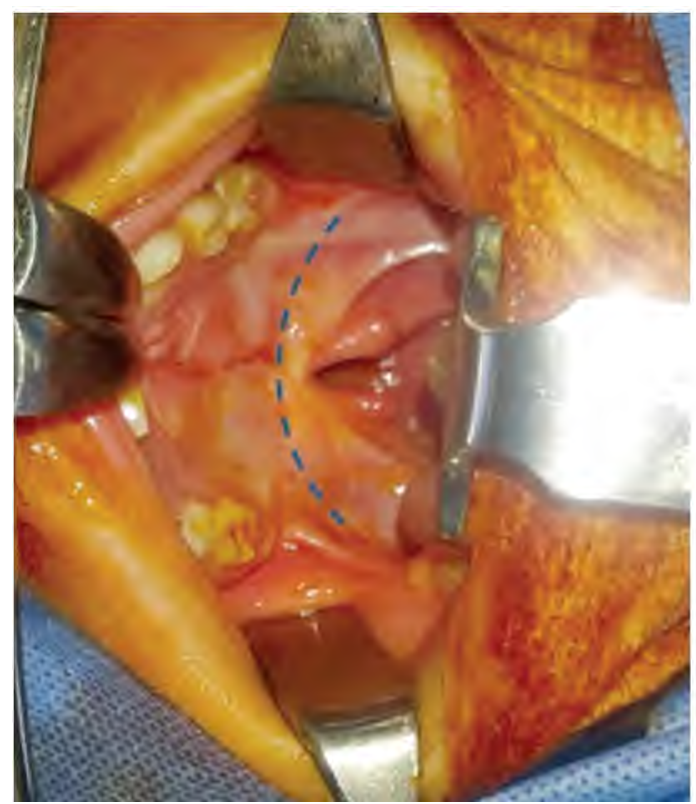

Fig. (1): The transverse incision between the hard palate and soft palate.

The operative parameters elected were the operative time, bleeding, length and width of the flaps, prolapse of the buccal pad of fat, nerve injury, and recovery.

Early postoperative parameters were the establishment of feeding, hospital stay, flap's integrity, donor site complications, snoring, and obstructive sleep apnea.

Postoperative follow-up was made twice weekly. The speech therapy started 1 month after operation. Three months later the auditory perceptual and soft palate (Fig. 1), the levator muscle is dissected completely from the abnormal attachment to the hard palate and repositioned in the transverse orientation leaving an anterior defect [4,5].

The other technique used was double opposing Z-plasty (Furlow). A Z-plasty of oral mucosa is performed (60-degree angel). The levator muscle is dissected from oral mucosa in right side and dissected from nasal mucosa on the other side. Another Z-plasty is made on the nasal mucosa. This allows the levator muscle to be repositioned posteriorly and a defect is made between the flaps.. The resulting defect in both techniques is reconstructed using posteriorly based buccinator myomucosal flap (Fig. 2) [8]. All patients received liquid oral intake by the operative day night. The pedicle is divided 1 month postoperative if needed.

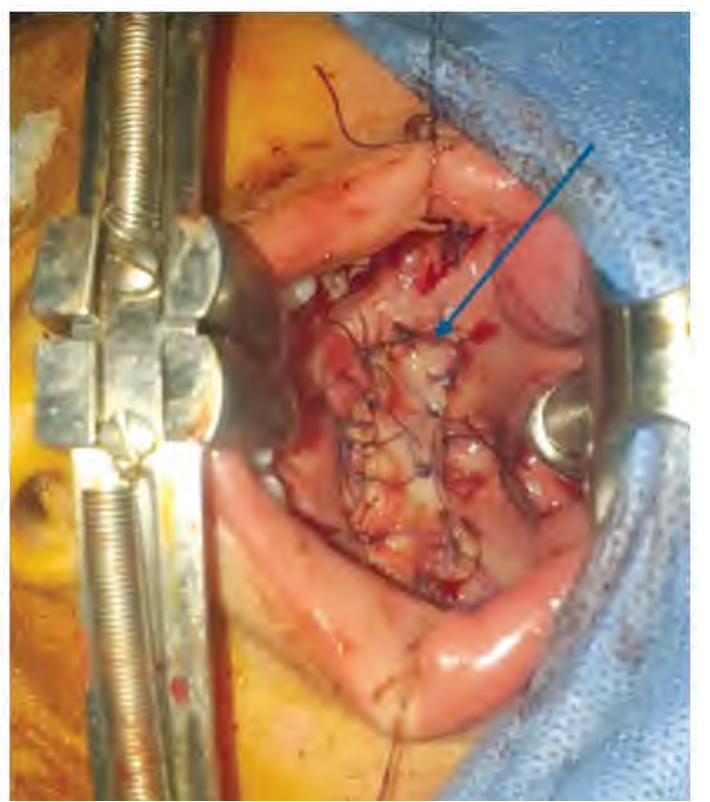

Fig. (2): Post-operative view after lengthening of the palateBuccinator flap (Arrow).

assessment and videofluroscopy were made. All parameters elected preoperatively were assessed again by experienced phoniatrician. APA parameters are hyper-nasality, nasal air emission, imprecision of consonants, glottal articulation, pharyngealization of fricatives, and unintelligibility of speech. All parameters were rated on 5 points scale from 0 (no) to 4 (severe). The cases was categorized as (completely improved, improved, and not improved). Videofluroscopy parameters were velar length, resting gap, and active gap. 


\section{Results}

\section{Criteria of the patients:}

Thirty patients were included. The mean age at the operation was $8 \mathrm{y} 2 \mathrm{~m} \pm 4 \mathrm{y} 2 \mathrm{~m}$. Females were 17 and males are 13. The original pathology was incomplete cleft palate in 17 cases, bipartite cleft palate in 10 cases, and 3 cases were tripartite.

\section{Surgical techniques:}

The mean operative time was 1 -hour \pm 9 minutes. The mean blood loss was $30 \pm 5.5 \mathrm{ml}$. The mean length of the flap was $68 \pm .74 \mathrm{~mm}$. The longest flap was $82 \mathrm{~mm}$ without stretch, while the shortest one was $52 \mathrm{~mm}$. The mean width of the flap was $16.8 \pm$ $3.7 \mathrm{~mm}$. The widest flap was $26 \mathrm{~mm}$, while the narrowest one was $12 \mathrm{~mm}$. Prolapse of the buccal pad of fat occurred in 5 cases and all of them returned and the space was sutured with no postoperative sequelae. No delayed recovery, there were No post-operative bleeding, No affection of normal breathing with any case.

All patients started feeding 4 hours postoperatively and tolerated semisolids by the same day night. All cases were discharged the next day morning. Evident cheek edema (donor site) occurred in 3 cases (10\%) with no affection of feeding or breathing. One of them needed readmission for another two days just for monitoring with no sequelae and was discharged free.

\section{Early postoperative assessment:}

The early postoperative period showed No flap affection with any case. All flaps were intact and viable for the follow-up period ( 3 months). No ischemia, no dehiscence, and no fistulas occurred. No case developed snoring, sleep disturbance, and/or mouth breathing.

\section{Postoperative assessment:}

Preoperatively, patients with high-grade hypernasality $(83.33 \%)$, high-grade nasal air emission $(80 \%)$, high grade of unintelligibility of speech (70\%), circular closure pattern (70\%), large velopharyngeal gap $(63.33 \%)$, limited velar mobility $(73.33 \%)$, and short velum (60\%).

Postoperatively, there was a progressive improvement of hypernasality, nasal air emission, intelligibility of speech, and overall velopharyngeal function (Table 1). There was a progressive reduction of the size of the gap, an increase in the velar mobility, an increase in the length of the palate, and an overall increase in the number of patients with complete velopharyngeal closure (Table 2). Three months after, there was an improvement of speech in $(83.33 \%)$ of all patients. It is related to the significant increase in palatal length and reduction of the velopharyngeal gap.

Table (1): Auditory perceptual assessment: Comparison between the number of cases with each grade before and after the operation.

\begin{tabular}{|c|c|c|c|c|c|c|}
\hline \multirow{2}{*}{$\begin{array}{l}\text { Improv- } \\
\text { ement }\end{array}$} & \multicolumn{2}{|c|}{$\begin{array}{c}\text { Hypernasality } \\
84 \%\end{array}$} & \multicolumn{2}{|c|}{$\begin{array}{c}\text { Nasal air } \\
\text { emission } \\
79.8 \%\end{array}$} & \multicolumn{2}{|c|}{$\begin{array}{c}\text { Unintelligibility } \\
\text { of speech } \\
83.3 \%\end{array}$} \\
\hline & Before & $\begin{array}{l}3 \mathrm{~m} \\
\text { After }\end{array}$ & Before & $\begin{array}{l}3 \mathrm{~m} \\
\text { After }\end{array}$ & Before & $\begin{array}{l}3 \mathrm{~m} \\
\text { After }\end{array}$ \\
\hline Grade 0 & 0 & 9 & 0 & 8 & 0 & 9 \\
\hline Grade 1 & 0 & 12 & 0 & 11 & 0 & 13 \\
\hline Grade 2 & 5 & 5 & 6 & 6 & 9 & 5 \\
\hline Grade 3 & 20 & 2 & 19 & 4 & 16 & 2 \\
\hline Grade 4 & 5 & 2 & 5 & 1 & 5 & 1 \\
\hline Mean \pm SD & $3 \pm .58$ & $.37 \pm 1.4$ & $2.96 \pm .61$ & $1.1 \pm 1.06$ & $2.86 \pm .68$ & $1.16 \pm .98$ \\
\hline
\end{tabular}

Table (2): Videofluroscopy assessment.

\begin{tabular}{|c|c|c|}
\hline $\begin{array}{l}\text { Pre-operative } \\
(\text { Mean } \pm \text { SD) }\end{array}$ & $\begin{array}{c}3 \text { month } \\
\text { postoperative } \\
(\text { Mean } \pm \text { SD })\end{array}$ & $\begin{array}{l}\text { The change } \\
\text { occurred }\end{array}$ \\
\hline \multicolumn{3}{|c|}{$\begin{array}{l}\text { Length of } 23.56 \pm 4.42 \mathrm{~mm} 31.57 \pm 2.92 \mathrm{~mm} \text { Increased by } \\
\text { the velum } \\
7.92 \pm 2.49 \mathrm{~mm}\end{array}$} \\
\hline \multicolumn{3}{|c|}{ Resting gap $11.74 \pm .41 \mathrm{~mm} 5.04 \pm 1.67 \mathrm{~mm}$ Decreased by $56.4 \%$} \\
\hline Active gap $7.4 \pm 3.2 \mathrm{~mm}$ & $1.83 \pm 1.99 \mathrm{~mm}$ & Decreased by $75.1 \%$ \\
\hline
\end{tabular}

\section{Discussion}

The success rate of the speech outcome was $(83.3 \%)$ and the rate of minor complications (10\%) which is comparable to the previous studies (48$96 \%$ and $8-31 \%)$ [4,5,8-15] respectively. Those studies have mixed groups of syndromic and nonsyndromic cases. Moreover, many of them evaluated the BMMF for fistulas and VPI too. Our study had a strictly defined group of children with post palatoplasty VPI who will undergone the operation for the management of VPI.

Our results show significant improvement of speech $(83.3 \%)$ which is comparable with other operations used for management of secondary VPI with less complication. Other studies showed an improvement up to $74 \%$ for Teflon injection, $85 \%$ for sphincter pharyngoplasty, $96 \%$ for pharyngeal flaps, $68 \%$ for fat grafting, and $82 \%$ for palatal rerepair [16-21]. Pharyngoplasties has its wellknown complication like the risk of hemorrhage, breathing problems, hyponasality, inability for naso-endotrachial intubation, and obstructive sleep apnea (OSA) [4]. OSA develops in about $80 \%$ of patients with dynamic pharyngoplasty 1 year after the operation [22]. 
Lateral videofluroscopy assessment, during rest, showed a significant increase in the palatal length with a mean $7.92 \mathrm{~mm}$ that is comparable with the result elected by Hens et al., [5] Which showed an average increase by $7.5 \mathrm{~mm}$. Rao et al., [23] study on BMMF with intravelar veloplasty for VPI management study showed a $61.5 \%$ reduction of the resting gap and increased the length of the velum by $7.5 \mathrm{~mm}$. In our study, the resting velopharyngeal gap decreased by $(57 \%)$ in size and the active gap decreased by $75 \%$. The defference in the percentages of reduction between resting and active gap is almost related to the better positioning and contraction of the levator muscle. The limited reduction in resting gap protects the patient from obstructive symptoms (e.g. OSA) and the significant reduction occurs in the active gap ameliorate the speech.

Buccinator myomucosal flaps are applicable in a wide variety of VPI patients of various ages, causes, closure pattern, number of previous surgeries, amount of palatal scarring. The idea of the restoration of normal anatomy by repositioning of levator muscle and lengthening of the velum by buccinators flaps is beneficial in every situation. Moreover, it is in line with the plastic surgery goal of restoration of normal anatomy [4]. Interestingly, it is a well-vascularized flap, elastic, malleable, close to the target site, has a sufficient length, width, and thickness. The technique is easy, quick, teachable, doesn't leave denuded periosteum which affects facial growth, a good choice in patients with difficult access to the pharynx, gives enough length to reduce the gap but without causing hypo nasality and/nor breathing problems.

One of the limitations of our study was the relatively short follow-up period, we predict a continuous improvement of the cases later on. Denadai et al., [24] made a serial evaluation 3, 6, and 12 months for 53 cases who underwent bilateral BMMF for VPI management. His evaluation after three months showed 4 patients only with no hypernasality $(10.8 \%)$ this number became $22(59.5 \%)$ patients with no nasality 12 months after the operation. Our evaluation after 3 months showed 9 $(30 \%)$ patients with no hypernasality. Better wound healing and adaptation of the patient for the mechanism of closure could explain this continuous improvement with time. However, unfortunately, we have no follow-up after 12 months.

Another limitation was the absence of a controlled group, but the intention of the study was the assessment of indications and outcomes of the buccinator myomucosal flap and levator muscle repositioning for management of VPI after palatal repair. Another larger series, with longer followup, and comparative groups is needed to reach a generalization of the technique.

\section{Conclusion:}

Buccinator myomucosal flaps and levator muscle repositioning is a reliable efficient procedure for the management of velopharyngeal insufficiency in non-syndromic cleft patients with minimal complications.

\section{References}

1- HOSSEINABAD H.H., DERAKHSHANDEH F., MOSTAAJERAN F., ABDALI H., DAVARI H.A., HASSANZADEH A. and KUMMER A.W.: Incidence of velopharyngeal insufficiency and oronasal fistulae after cleft palate repair: A retrospective study of children referred to Isfahan Cleft Care Team between 2005 and 2009. International Journal of Pediatric Otorhinolaryngology, 79 (10): 1722-1726, 2015.

2- GART M.S. and GOSAIN A.K.: Surgical management of velopharyngeal insufficiency. Clinics in Plastic Surgery, 41 (2): 253-270, 2014

3- COLLINS J., CHEUNG K., FARROKHYAR F. and STRUMAS N.: Pharyngeal flap versus sphincter pharyngoplasty for the treatment of velopharyngeal insufficiency: A meta-analysis. Journal of Plastic, Reconstructive \& Aesthetic Surgery, 65 (7): 864-868, 2012.

4- HILL C., HAYDEN C., RIAZ M. and LEONARD A.G.: Buccinator sandwich pushback: A new technique for treatment of secondary velopharyngeal incompetence. The Cleft Palate-Craniofacial Journal, 41 (3): 230-237, 2004.

5- HENS G., SELL D., PINKSTONE M., BIRCH M.J., HAY N., SOMMERLAD B.C. and KANGESU L.: Palate lengthening by buccinator myomucosal flaps for velopharyngeal insufficiency. The Cleft Palate-Craniofacial Journal, 50 (5): 84-91, 2013.

6- REDDY R.R., REDDY S.G., BANALA B., BRONKHORST E., KUMMER A.W., KUIJPERS-JAGTMAN A.M. and BERGÉ S.J.: Use of a modified Furlow Z-plasty as a secondary cleft palate repair procedure to reduce velopharyngeal insufficiency. International Journal of Oral and Maxillofacial Surgery, 45 (2): 170-176, 2016.

7- AFROOZ P.N., MacISAAC Z., ROTTGERS S.A., FORD M., GRUNWALDT L.J. and KUMAR A.R.: A comparison of speech outcomes using radical intravelar veloplasty or Furlow palatoplasty for the treatment of velopharyngeal insufficiency associated with occult submucous cleft palate. Annals of Plastic Surgery, 74 (2): 182-186, 2015.

8- LOGJES R.J.H., van den AARDWEG M.T.A., BLEZER M.M.J., van der HEUL A.M.B. and BREUGEM C.C.: Velopharyngeal insufficiency treated with levator muscle repositioning and unilateral myomucosal buccinator flap. Journal of Cranio-Maxillofacial Surgery, 45 (1): 1-7, 2017.

9- DIAS D.K., FERNANDO P.D.C. and DISSANAYAKE R.D.A.: Improvement of quality of speech in patients with velo-pharyngeal insufficiency corrected using a 
buccinator myomucosal flap. Ceylon Medical Journal, 61(3), 2016.

10- LEE J.Y. and ALIZADEH K.: Spacer facial artery musculomucosal flap: simultaneous closure of oronasal fistulas and palatal lengthening. Plastic and Reconstructive Surgery, 137 (1): 240-243, 2016.

11- AHL R., AHMAD T., HARDING-BELL A., WHARTON L., JORDAN A. and HALL P.: The Buccinator mucomuscular flap: an in-depth analysis and evaluation of its role in the management of velopharyngeal dysfunction. The Cleft Palate-Craniofacial Journal, 53 (5): 177-184, 2016.

12- VARGHESE D., DATTA S. and VARGHESE A.: Use of buccal myomucosal flap for palatal lengthening in cleft palate patient: Experience of 20 cases. Contemporary Clinical Dentistry, 6 (Suppl 1): S36, 2015.

13- ABDALY H., OMRANYFARD M., ARDEKANY M.R. and BABAEI K.: Buccinator flap as a method for palatal fistula and VPI management. Advanced Biomedical Research, 4, 2015.

14- MANN R.J., NEAMAN K.C., ARMSTRONG S.D., EBNER B., BAJNRAUH R. and NAUM S.: The doubleopposing buccal flap procedure for palatal lengthening. Plastic and Reconstructive Surgery, 127 (6): 2413-2418, 2011.

15- ROBERTSON A.G., McKEOWN D.J., BELLO-ROJAS G., CHANG Y.J., ROGERS A., BEAL B.J. and JACKSON I.T.: Use of buccal myomucosal flap in secondary cleft palate repair. Plastic and Reconstructive Surgery, 122 (3): 910-917, 2008.

16- FURLOW J.L., BLOCK A.J. and WILLIAMS W.N.: Obstructive sleep apnea following treatment of velopharyngeal incompetence by Teflon injection. The Cleft Palate Journal, 23 (2): 153-158, 1986.

17- SHEWMAKE K., ELIAS D., FROMWILLER S. and KAWAMOTO H.: Modification of the Orticochea pharyn- goplasty for the correction of velopharyngeal insufficiency: Seven-year experience. In: Presented at the annual meeting of the American Clef Palate Craniofacial Association, Portland, 1992.

18- RISKI J.E., RUFF G.L., GEORGIADE G.S., BARWICK W.J. and EDWARDS P.D.: Evaluation of the sphincter pharyngoplasty. The Cleft Palate-Craniofacial Journal, 29 (3): 254-261, 1992.

19- ARGAMASO R.V.: Pharyngeal flap surgery for velopharyngeal insufficiency. Operative Techniques in Plastic and Reconstructive Surgery, 2 (4): 233-238, 1995.

20- SOMMERLAD B.C., MEHENDALE F.V., BIRCH M.J., SELL D., HATTEE C. and HARLAND K.: Palate rerepair revisited. The Cleft Palate-Craniofacial Journal, 39 (3): 295-307, 2002.

21- BONETI C., RAY P.D., MacKLEM E.B., KOHANZADEH S., de la TORRE J. and GRANT J.H.: Effectiveness and safety of autologous fat grafting to the soft palate alone. Annals of Plastic Surgery, 74: S190-S192, 2015.

22- MADRID J.R.P., ORTEGA V.G., ECHEVERRI P. and VELASQUEZ N.L.: Prevalence of obstructive sleep apnea after orticochea pharyngoplasty for velopharyngeal insufficiency management. Cleft Palate-Craniofacial Journal, 52 (6): 682-687, 2015.

23- RAO T.M., SRIKANTH R. and RAMBABU N.: Original Research Paper Plastic Surgery Evaluation of the efficacy nof Buccal Myomucosal Flap for the Correction of VPI in Primary Cleft Palate. D. Mukunda Reddy, (8): 2-6, 2019.

24- DENADAI R., SABBAG A., AMARAL C.E.R., PEREIRA FILHO J.C., NAGAE, M.H. and AMARAL C.A.R.: Buccinator myomucosal flap for the treatment of velopharyngeal insufficiency in patients with cleft palate and/or lip. Brazilian Journal of Otorhinolaryngology, 84 (6): 697707, 2018. 


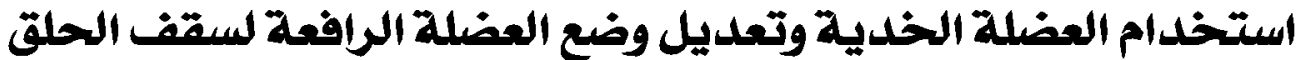

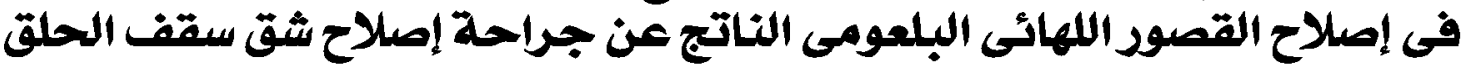

يعد القصود اللهائى البلعومى من المشكلات الشائعة والتى تحدث بنسبة تتراوح بين وللمرضى الذين يخضعون لإجراء جراحة إصلاح شق سقف الحق. الهدف من الدراسة: تستهدف هذه الدراسة تقييم استخدام العضلة الخدية وتعديل وضع العضلة الرافعة لسقف الحلق فى إصلاح القصور

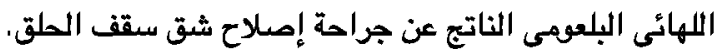

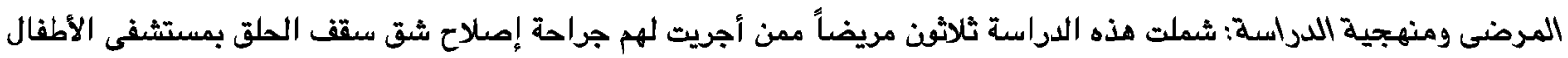

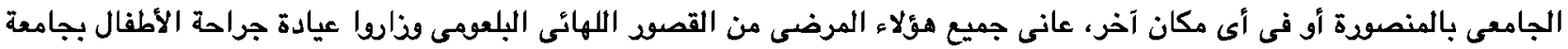

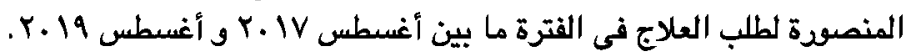

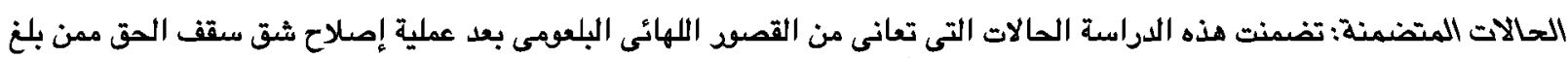

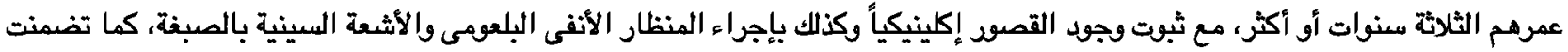

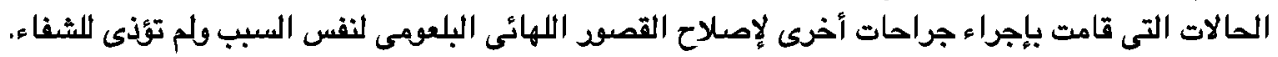

الحالات المستبعدة: لم تتضمن هذه الدراسة الحالات التى لم تبلغ ثلاثة سنوات من العمر، وكذالك لم تتضمن الحالات العات التى تعانى من

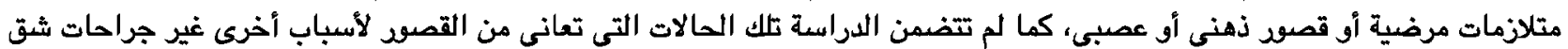
سقف الحق. التدخل الجراحى: خضعت الحالات لتقييم جودة النطق بالاختبار الإدراكى السمعى، وتم تقييم حالة سقف الحلق بالمنظار الأنفى البلعومى

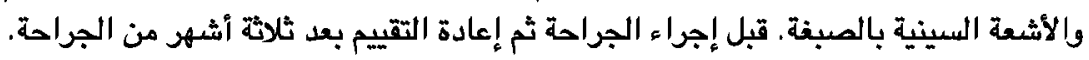
- أجريت جميع الجراحات تحت تأ ثير المخدر الكلى. - تتضمن الجراحة تعديل وضع العضلة الرافعة لسقف الحلق لوضعها العرضى الطبيعى، مع إطالة سقف العلق باستخدام سدلة من العضلة الخدية.

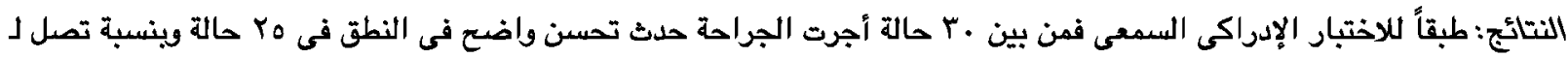

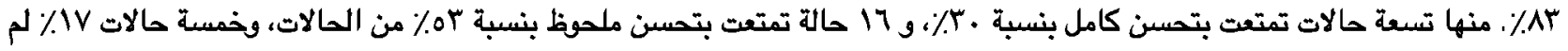
يلاحظ التحسن عليها. - طبقاً للمنظار الأنفى البلعومى: لوحظ تحسن واضع فى حركية سقف الحلق فى سبعة وعشرين حالة ( 9٪) وكذلك انخفاض فى قياس الفجوة

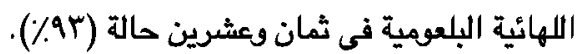

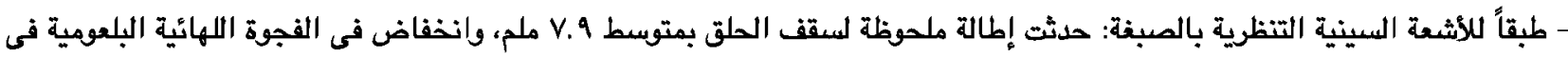

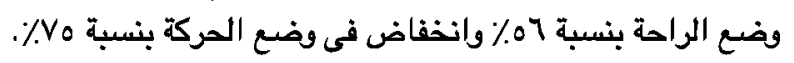

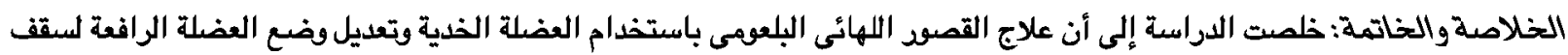

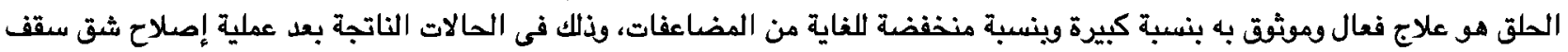

